\title{
Poznámky v žákovských knížkách: koalice, nebo konflikt mezi rodinou a školou?
}

\section{Critical comments in students' books: school-family coalition or conflict?}

\author{
Irena Smetáčková
}

\begin{abstract}
Abstrakt: Žákovské knížky lze vnímat jako prostředek komunikace mezi rodinou a školou. Údaje, které se jimi předávají, se týkají organizace školního života, prospěchu v jednotlivých předmětech a chování dítěte. Sdělování jednotlivých typů informací se řídí specifickými pravidly. Př́íspěvek se zabývá konkrétně poznámkami v žákovských knížkách, a to jejich obsahem, formou a rodičovskou reakcí. Hlavní pozornost je položena na funkci poznámky ve vztahu mezi rodinou a školou. Příspěvek je dílčím výstupem z výzkumu, který se zabývá aktuální podobou a účelem žákovských knížek 360 žáků a žákyň základních škol.
\end{abstract}

Klíčová slova: komunikace mezi rodinou a školou, žákovské knížky, poznámky, nekázeň

\begin{abstract}
Students' books can be considered as a tool of communication between school and family. Transfer information is related to an organization of school life, achievements in different subjects and child behavior. Transmission of each information has the own rule. The paper is focused on critical comments at child behavior - their content, form and parents' answer. The results are based on the analysis of 360 students' books.
\end{abstract}

Keywords: school-family communication, student's book, critical comments, discipline

\section{1 Úvod - představení výzkumu}

Ačkoliv se žákovské knížky (dále jen ŽK) nebo určitá jejich obdoba používají na všech českých základních školách, jednotlivé školy i tř́ídy vykazují značné rozdíly týkající se účelu ŽK, jejich grafické podoby a práce s nimi. Společným jmenovatelem ŽK je shromažd’ování a předávání informací o školním životě. V tomto smyslu je tedy ŽK vždy nástrojem komunikace, a to komunikace nepř́mé (Deslandes, 2009; Carvalho, 2001). Ovšem - o čem se komunikuje, kdo je původcem komunikace, kdo je jejím př́ijemcem, jaké záměry a očekávání jsou skomunikací spojeny? V těchto aspektech existuje vysoká variabilita, která v pedagogické praxi ústí ve vytvoření řady rozdílných modelů ŽK a jejich postavení ve výuce.

Jejich zmapování se stalo cílem šetření, které náleží do širšího výzkumu zabývajícího se aktuální podobou vztahů mezi institucí školy a rodiny ${ }^{1}$. V rámci šetření byly analyzovány ŽK a notýsky od 360 dětí z 18 trríd devíti ročníků základních škol z celé České republiky, které obsahovaly záznamy z prvních čtyř měsíců školního roku 2010/2011². Dále bylo použito pozorování výuky a rozhovory s vyučujícími i vybranými žáky/němi, které zjišt’ovaly, jaké jsou postoje aktérů k ŽK a jaké je reálné zapojení ŽK do výuky. Přri zpracování dat byly

\footnotetext{
${ }^{1}$ Výzkum „Nové formy komunikace mezi rodinou a školou“, GAČR 406/09/0910.

${ }^{2}$ Sběr dat probíhal s pomocí studujících katedry psychologie, kterým patří poděkování. Výběr škol sledoval jednak kritérium dostupnosti a ochoty, jednak kritérium pestrosti výsledného souboru.
} 
použity jak kvalitativní postupy (obsahová a diskurzivní analýza), tak statistické procedury (testování průměrů, korelace, faktorová analýza).

Rozbor obsahu ŽK ukázal, že obsažené údaje lze členit do tř́ skupin: 1) informace k organizaci školního života, 2) známky z jednotlivých předmětů informující o průběhu a výsledcích učení, 3) komentáře týkající se chování dítěte, tj. poznámky a pochvaly. Tento př́spěvek se zaměřuje pouze na poznámky ve smyslu kritických komentáŕù k žákovskému chování a/nebo výkonu.

\section{Explicitní obsah a implicitní záměr poznámek}

Obecně lze konstatovat, že poznámky informují o nesplnění určité povinnosti či porušení pravidla. Obsahová analýza ukázala, že lze poznámky trrídit do následujících devíti skupin: 1 . Pozdní prí́chody: Přišel pozdě do výuky; 2. Zapomínání pomůcek: Neměla materiál na VV, nemohla pracovat; 3. Zapomínání úkolů: Nemá úkol z matematiky - už podruhé; 4. Nepřipravenost na výuku: Během ř́jna nebyla $3 x$ rádně připravena na hodinu; 5. Nepřipravenost při zvonění: $O$ prestávce běhal po chodbě, což je zakázáno, misto toho, aby se chystal na hodinu; 6. Drzé chování vůči učiteli: Odmlouvá; 7. Vyrušování ve výuce: Přes opakované napomínáni ruší; 8. Ne-práce: Misto čtení si hraje s penálem; 9. Ubližování: Fyzicky napadl spolužáka.

První čtyři typy poznámek upozorňují na selhání dítěte v rámci domácí př́ípravy, a směřují proto implicitně vůči rodičům. Zbývajících pět typů poznámek se týká selhání dítěte v rámci školy. Jak ukázaly rozhovory s vyučujícími, poznámky jsou vnímány jako krajní řešení nekázně a pro některé dokonce jako řešení zcela vyloučené, nebot' jím přiznávají vlastní profesionální neúspěch. Poznámka je podle nich důkazem, že dítě nedokáží usměrnit sami, a proto potřebují rodiče přivolat na pomoc. To se však týká pouze druhé skupiny poznámek; $\mathrm{v}$ př́padě první, která se týká nedostatku v domácí přípravě, je naopak institut poznámek $\mathrm{i}$ vyučujícími, jež odmítají písemně kritizovat chování dětí, četně využíván.

Popsaný rozdíl se v našem výzkumu ukázal jako nejčastější, avšak jeho platnost je závislá na učitelské představě o rozdělení kompetencí mezi rodinu a školu. Vyučující vždy vycházejí ze specifického modelu, v němž každá strana má svojí zodpovědnost za část školní úspěšnosti (Rabušicová, 2004; Štech, 2004). Dobřre to ilustruje případ učitelky, která neuděluje poznámky, protože se domnívá, že rodiče mají škole poskytovat pouze obecnou podporu, ale jinak do výuky či prŕpravy nevstupovat. Získat děti pro školní povinnosti a školní pravidla učitelka chápe jako svi̊j úkol. Zároveň považuje za důležité vést děti k samostatnosti. Pokud se tedy žáci/kyně chovají neukázněně či se řádně nepřipravují na výuku, řeší to jen s nimi.

Ještě zřetelněji je význam představy o vztahu rodiny a školy vidět na účelu poznámek. Na základě analýzy všech zdrojů dat jsme identifikovali následujících pět cílů, s nimiž jsou poznámky udělovány: 1. disciplinace dítěte ve výuce (resp. skupiny), s aspirací na okamžitou změnu chování; 2. pouhé informování rodičů, bez aspirace na jejich zásah; 3. poskytnutí učitelského pohledu, s aspirací vytvořit koalici s rodiči; 4. stížnost na dítě, s aspirací na výchovný zásah rodičů a tím na následnou změnu chování; 5 . stížnost na rodiče, s aspirací na změnu jejich chování vůči škole. Ačkoliv ve většině případů, kdy jsou poznámky udělovány, se zároveň vyskytuje několik z těchto cílů, jejich váha se mění v závislosti na situaci a na perspektivě konkrétního aktéra, včetně jeho pojetí rodinných a školních kompetencí. Představa o striktních hranicích mezi rodinou a školní socializací vede k upřednostňování prvního a druhého cíle, zatímco naopak požadavek vzájemného prolínání školy a rodiny koresponduje s třetím až pátým cílem. 
Záměr poznámky ovlivňuje i její konkrétní znění. Většina formulací má charakter úředního dokumentu, který představuje věcné stručné informování o stavu - Nekázeň v hodině; Časté zapomínání. Stylisticky v těchto poznámkách absentuje oslovení adresáta i identifikace objektu. Naproti tomu menší část poznámek tyto prvky (či alespoň jeden z nich) obsahuje. Objektem bývají zpravidla děti, adresátem rodiče či děti: Kubo, rušišs ostatní při práci; Váš syn konzumuje bez dovolení v hodině bonbóny a po napomenutí je drzý; Paní Nová, Jan nemá opět sešit z ČJ. Svým zněním, které kombinuje institucionální (škola-rodina) a individuální (konkrétní rodič-konkrétní učitel/ka) závazek, vytváŕí na rodiče i děti větší tlak, aby výhradu akceptovali a napravili ji.

Hlavními zamýšlenými i reálnými př́jemci poznámek jsou rodiče. Jejich reakce ukazují stanovisko vůči události a obecnější postoj ke škole. V datech jsme nalezli několik typů rodičovských reakcí. Nejběžnější je podpis, kterým rodiče stvrzují, že poznámku četli, přičemž vyučující předpokládají, že ji zároveň akceptují. Při absenci podpisů je povinnost reagovat připomenuta: $Z ̌ K ~ u \check{~ d v a ~ t y ́ d n y ~ b e z ~ p o d p i s u ̛ ! ; ~ P r o s i ́ m ~ o ~ p o d p i s y . ~ D r u h y ́ m ~ t y p e m ~}$ reakce je explicitně souhlasná odpověd': Děkuji; Zajistíme nápravu. Takové se objevují zejména na začátku školní docházky nebo u dětí, pro které je poznámka zcela ojedinělý jev. Odpověd', která překračuje implicitní souhlas obsažený v pouhém podpisu, představuje rodičovské potvrzení autority učitele/ky a ochotu $\mathrm{k}$ vytvoření koalice „,proti“ dítěti. Třetím typem je vysvětlující odpověd', jejímž záměrem bývá zasadit události do širšího kontextu a tím změnit její vyznění: Až do 21,30 jsme dělali úkol z ČJ. Pak už byl moc unavený. Latentně oponující tón je posílen ve čtvrtém typu odpovědi, kterou je explicitní nesouhlas s pedagogickým prŕstupem nebo s udělením poznámky. Př́kladem oponování je rodičovská odpověd' na poznámku o soustavném vyrušování: Paní učitelko, můžete Járu více zaměstnat? Myslím, že poznámky nic neřeší. Děkuji. Posledním typem odpovědi je osobní kontakt, který představuje obvykle vyhrocený př́ípad vysvětlující či nesouhlasné odpovědi.

Povaha a účel poznámek závisí na fázi školní socializace a na době, po kterou spolu obě strany komunikují. Na začátku školní docházky a/nebo spolupráce mezi konkrétními rodiči a vyučujícími slouží poznámky $\mathrm{k}$ ustavování rodinných a školních kompetencí. Skrze poznámky vyučující formulují pravidla, jejichž dodržování po dětech i rodičích žádají: Třetí pozdni př́chod. Vod'te své děti včas. Děkuji.; Podepisujte ŽK a DÚ každý den! Posléze dochází po určitou dobu k relativně tolerantnímu připomínání a objasňování pravidel, což ilustruje např́iklad apel na podpisy: ŽKK už dva týdny bez podpisů! Když je vztah formálně konstituován, slouží poznámky k boji o změnu původního rozdělení kompetencí. Do této fáze patří většina nesouhlasných rodičovských odpovědí nebo např́íklad poznámka s pokynem, co mají rodiče udělat: Soustavné nevhodné chováni při hodinách. Drzá. Domluvte ji!! Součástí této fáze je i otevřená kritika rodiny: Petr je nesoustředěný a unavený. Do školy musi chodit odpočinutý. Upravte mu spánkový režim. Poznámky vychází z asymetrického vztahu mezi oběma institucemi, který dovoluje škole rodiče disciplinovat.

\section{Není poznámka jako poznámka}

Shromážděné ŽK a notýsky obsahovaly za sledované období celkem 432 poznámek, což v průměru představuje 1,2 poznámky na dítě. Počet poznámek výrazně varioval ${ }^{3} \mathrm{z}$ hlediska věku dětí (s věkem dětí počet poznámek rostl), z hlediska genderové kategorie (chlapci obdrželi významně více poznámek než dívky) a z hlediska osobnosti učitelky/e (udílení poznámek souvisí s pojetím učitelství, konkrétně s představou kázně a s představou vztahu

\footnotetext{
${ }^{3}$ Příspěvek prezentuje výsledky kvalitativní analýzy, kvantitativní údaje jsou pouze doplňkové, a proto stručné. Nicméně uváděné rozdíly jsou statisticky významné na hladině 0,05 .
} 
mezi rodinou a školou). Kombinací parametrů vznikají specifické poznámkové profily tříd. I $\mathrm{v}$ prrípadě tříd $\mathrm{s}$ celkovým vysokým podílem poznámek, existují jak předměty, tak děti, u nichž jsou poznámky nepř́ítomné či výjimečné.

Jak již bylo patrné v předchozí kapitole, poznámky jsou funkcí individuálních charakteristik dětí, tř́́dního kolektivu, pedagogického přístupu učitele/ky a situace. Relační povaha poznámek předpokládá, že aby se jim děti vyhnuly, musí rozumět a respektovat požadavky konkrétního učitele/ky, které ovšem mohou být specifické pro danou třídu a/nebo situaci. V našem šetření se ukázalo, že děti si tohoto východiska nejsou plně vědomi, a proto ani nedokážou proniknout do pravidel, kterými je nutné se ř́dit. Dokonce i u vyučujících převládá spíše intuitivní pojetí pravidel a institutu poznámky jako evidence jejich porušení. Vyústěním je poměrně neuchopitelný systém sankcí, podle něhož je obtížné vědomě regulovat vlastní chování. Jedním z př́ikladů nekoherence je zapisování poznámek za totožné přestupky do ŽK či notýsků, ačkoliv váha obou médií je různá. Vyučující tuto rozdílnost plně nereflektují (zvláště udělují-li poznámky $\mathrm{v}$ afektu), zatímco děti pod vlivem jejich orientace na spravedlnost výskyt rozporných reakcí registrují a snaží se v nich nalézt řád. Jejich vysvětlení zahrnuje třídění situací ( $k d y z ̌$ už ho někdo štve dlouho, dává poznámky, jinak si to s námi vyř́di rovnou ve tř́dě), typologii dětí (je prostě zasedlá na kluky), prrípadně osobnost učitele/ky (je náladový, záleží na tom, jak se vyspí).

Zcela jiný př́klad rozdílnosti v poznámkách představuje následující soubor zápisů u konkrétního žáka: 1) Matěj povidá při vyučování; 2) Upovídaný; 3) I přes opakované napomínání stále vyrušuje; 4) Uděluji třídní napomenutí za nekázeň. Všechny poznámky se vztahují k obdobnému chování, ale jejich podoba i vyznění se liší. Kritika graduje a stává se formálnější - od relativně osobního a vstřícného upozornění až k užití institutu důtky třídního učitele. Změna tónu korespondující s nárůstem nespokojenosti učitelky s chováním Matěje byla učitelkou interpretována jako záměrná a zároveň byla srozumitelná pro ostatní žáky/ně.

Soubor poznámek ilustruje obecný aspekt poznámek, kterým je opakování. Pro všechny skupiny aktérů se legitimnost poznámek odvíjí od toho, že jsou krajním řešením. Ve znění poznámek proto často figuruje průběhový čas a slova naznačující vysokou frekvenci porušování pravidel - zapomínání (místo zapomenutí), opět, opakovaně atd. Bez jejich přítomnosti poznámky pưsobí jako nepřiměřené a mohou snadněji vyznít v neprospěch vyučujících - totiž jako jejich profesní selhání při ukázňování dětí.

Druhým obvyklým aspektem poznámek je obecnost formulací: Vyrušuje; Nekázeň v hodině. Podrobnosti o situačním kontextu a chování v poznámkách obvykle chybí (zvláště v 6.-8. typu, viz výše). Obecnost zápisu znemožňuje rodičům rozumět tomu, jakého konkrétního chování se dítě dopustilo a které pravidlo porušilo. Tím se omezuje možnost, aby rodiče dítě adekvátně pro-školně usměrnili. Respektive se tím po rodičích žádá, aby zasáhli nespecificky ve prospěch školy a předpokládali apriorní platnost učitelského pohledu. Přijetím obecné poznámky tak rodiče de facto stvrzují, že respektují autoritu instituce školy, která je zastupována konkrétním učitelem/kou. V některých př́padech však rodiče tuto polohu „slepé“ akceptace odmítají.

Obecné formulace navozují úřední žánr, který mezi poznámkami převládá. Vedle něho však existuje žánr osobní neformální komunikace a žánr afektivní exprese. Poznámky spadající do těchto doplňkových žánrů vykazují větší detailnost, čímž se stávají zdrojem zapojení rodičů do školního dění. Rozdíl mezi poznámkami osobního neformálního žánru a afektivního žánru spočívá jednak ve vstř́icnosti tónu a jednak ve vztahu k popisované situaci. V prvním př́padě bývá poznámka udělena $\mathrm{v}$ časovém či emočním odstupu od události, $\mathrm{v}$ druhém prípadě je řešením „ted’ a tady“. Detaily afektivních poznámek často působí nepřriměřeně až směšně: Při VV číhal na okamžik, kdy spolužák odešel od stolu a pokusil se mu zcizit foukací fixu - 
modrou! Vzal jí a schoval k sobě pod triko. Chytila jsem ho př́mo v akci. Vyučující si jsou rizika komičnosti, které může ohrožovat jejich učitelskou autoritu, vědomi, a proto část z nich volí jako obrannou strategii časový odstup od události nebo dokonce úplné odmítání písemných poznámek. Reagují tím na skutečnost, že poznámky náleží do skripturální kultury, která se řídí odlišnými mechanismy než kultura orální - písemně fixované informace nabývají na závažnosti (Olson, 1996).

\section{Závěr: poznámky jako platforma vztahu mezi rodinou a školou}

Poznámky jsou jedním z faktorů, které se podílejí na utváření vztahu mezi rodinou a školou. Zároveň jsou ale také zrcadlem, v němž se ukazuje, jaký vztah mezi oběma institucemi aktuálně panuje. V př́ípadech, kdy se představa vyučujících a rodičů o rozdělení kompetencí mezi instituce rodiny a školy shoduje, dochází k tomu, že rodiče poznámky akceptují a mezi oběma stranami se vytváří koalice „proti““ dítěti. V opačném případě nastává nedorozumění či konflikt. Jeho riziko se zvyšuje tím, že vyučující s pravidly a tresty za jejich porušování pracují značně intuitivně. Na straně dítěte i rodičů proto vzniká nejistota, v níž regulace chování není zcela efektivní. Značnou výhodu v takto nečitelné situaci získávají děti disponující vyšším sociálním citem, který jim dovoluje odhadovat učitelské požadavky, a př́padně jejich rodiče, kteří volí adekvátnější reakce, včetně odpovědí nesouhlasných, které jsou ovšem užity v takové situaci a takovým způsobem, že vyučující přesvědčí o pravdivosti rodičovského postoje.

\section{Literatura}

Carvelho, M. E. P. de (2001). Family-School relations: A critique of parentel involvment in schooling. Mahwah, NJ: Lawrence Erlbaum Associates.

Deslandes, R. (Ed.). (2009). International perspective on student outcomes and homework. New York: Routledge.

Rabušicová, M., Šed’ová, K., Trnková, K., \& Čiháček, V. (2004). Škola a /versus/ rodina. Brno: MU. Štech, S. (2004). Angažovanost rodičů ve školní socializaci dětí. Pedagogika, 54(4), 374-388.

Olson, D. R. (1996). The world on paper. Boston: Cambridge University Press.

\section{Kontakt}

PhDr. et. Mgr. Irena Smetáčková, Ph.D.

Univerzita Karlova v Praze

Pedagogická fakulta, Katedra psychologie

Myslíkova 7, 11000 Praha 1

e-mail: irena.smetackova@pedf.cuni.cz

\section{Bibliografické údaje}

Smetáčková, I. (2011). Poznámky v žákovských knížkách: koalice, nebo konflikt mezi rodinou a školou? In T. Janík, P. Knecht, \& S. Šebestová (Eds.), Smíšený design v pedagogickém výzkumu: Sborník př́spěvků z 19. výročni konference České asociace pedagogického výzkumu (s. 125-129). Brno: Masarykova univerzita.

Dostupné z: http://www.ped.muni.cz/capv2011/sbornikprispevku/smetackova.pdf doi: 10.5817/PdF.P210-CAPV-2012-65 